\title{
COMPARATIVE ANALYSIS OF FEMALE ELITE BIATHLETES' SPORTS RESULTS IN WORLD CUP COMPETITIONS BEFORE THE WORLD CHAMPIONSHIP AND DURING THE WORLD CHAMPIONSHIP IN THE SEASON OF 2010-2011
}

\author{
Natalja Kočergina, Algirdas Čepulėnas, Aurelijus Zuoza \\ Lithuanian Academy of Physical Education, Kaunas, Lithuania
}

\begin{abstract}
Research background and hypothesis. Modern training trend for biathletes is the increasing intensity of the training process in competition activities. Competition activities of elite biathletes while preparing for the main competition of the season have received little attention by researchers. Research hypotheses: The number of starts and sports results in the competitions before the main competition of the season for elite biathletes are related to sports results in the main competition of the season.

Research aim was to analyse the interaction of biathletes' sports results and the number of starts, and to establish the relation of this interaction between the results achieved in World Cup competitions and World Biathlon Championship.

Research methods. The data have been retrieved from the documents of the International Biathlon Union (IBU): protocols of the World Biathlon Championship of 2011 and World Biathlon Cup competition. We analysed the sports results of female biathletes who took the $1^{\text {st }}-10^{\text {th }}$ places in the World Biathlon Championship in individual events.

Research results. World elite biathletes participated in E.ON and IBU category competitions $16.2 \pm 3.74$ times before the World Biathlon Championship. The number of starts correlates with the places taken by biathletes in the general account of the World Biathlon Cup before the world championship $(r=-0.83)$. In the individual races in the World Championship, all medals were won by eight skiers, and five of them were among the first ten skiers in the general standing of World Cup competitions before the world championship.

Discussion and conclusion. The preparation of elite biathletes for the most important competition of the season World Biathlon Championship is grounded on the repeated participation in the World Biathlon Cup competitions. Biathletes, taking the $1^{\text {st }}-10^{\text {th }}$ places in the general account of the World Biathlon Cup, are real applicants for medals in the World Biathlon Championship.
\end{abstract}

Keywords: number of starts, taken places, correlation, sprint, pursuit, mass start, individual start.

\section{INTRODUCTION}

$\lceil$ in ne period of competitions, participation in competitions and the loads of competitive activities improve the body adaptation to competitive activities (Pustovrh et al., 1995; Suslovas, 1999; Платонов, 2004). For some elite athletes in cyclic branches of sport competitive loads become the loads of special athletic training in the period of competitions. During the last 10-15 years athletes' results have been rapidly improving due to the increase in the number of competitions in the competition calendar in that branch of sports, but because of frequent participation in the competitions, the leaders of the season cannot achieve the results which were planned for them in the main competitions (Olympic Games, World Championships) (Суслов, 2002; Платонов, 2009). 
In biathlon skiing races, predictions are confirmed only in $20-25 \%$ of cases (Платонов, 2009). The competition result in biathlon depends on the time to cover the skiing distance and on accurate shooting. During the competition, biathletes are affected by external factors (competition environment, competitors, spectators, weather conditions, and the terrain of the ski slopes) and internal factors (tension, anxiety, joy, fear). Those irritants cause psychological reactions which improve or worsen the final outcomes (Schmolinsky, 2000). It is very difficult to evaluate the influence of athletes' athletic fitness component on their results in the competitions (Cholewa et al., 2005).

Modern training trend for biathletes is the increasing intensity of the training process in competition activities, individual optimization of competition activities according to individual training plan for the most important competition of the season - World championship (Cholewa et al., 2005; Преображенцев, 2007). Competition activities of elite biathletes while preparing for the main competition of the season have received little attention by researchers.

Research aim was to analyse the interaction of biathletes' sports results and the number of starts, and to establish the relation of this interaction between the results achieved in World Cup competitions and World Biathlon Championship.

Research object - indices of competition activities of biathletes who took the $1^{\text {st }}-10^{\text {th }}$ places in the World Biathlon Championship of 2011.

\section{RESEARCH METHODS}

The data have been retrieved from the documents of the International Biathlon Union (IBU): biathletes' results in the competition of E.ON IBU category, protocols of the World Biathlon Championship of 2011 and World Biathlon Cup competition (Biathlon ${ }^{1-4}$, http://www. biathlonworld3.de.html). We analysed the sports results of female biathletes who took the $1^{\text {st }}-10^{\text {th }}$ places in the World Biathlon Championship in individual events. The research sample included 20 high-capacity world biathletes. The data were processed applying Microsoft Excel 2003 programme and special statistical programme SPSS 12.0 for Windows. We calculated arithmetic means, standard deviations (SD), coefficients of correlation (r). Regression analysis of the data was performed.

\section{RESEARCH RESULTS}

In the season of 2010-2011 there were 19 individual biathlon races in the women's programme in the World Biathlon Cup competition before the beginning of the World Biathlon Championship: 11 of them were middle and long distance races (pursuit $-10 \mathrm{~km}$, individual start $-15 \mathrm{~km}$, mass start $-12.5 \mathrm{~km}$ ) and eight sprint competitions $7.5 \mathrm{~km}$. The first biathlete in the general account of the World Biathlon Cup competition was German biathlete H. A. She participated in competitions 19 times. In the World Biathlon Championship Biathlete $\mathrm{H}$. A. did not win any medal in individual events, and her best result was only the fourth place in $10 \mathrm{~km}$ pursuit race. In other distances she took the $13^{\text {th }}, 20^{\text {th }}$, and the $46^{\text {th }}$ places (Table). In the World Biathlon Championship the best biathlete was M. K. who won two gold medals and one silver medal. Before the world championship she participated in competitions 17 times and in general she was in the fifth place. It is interesting to note that biathletes B. T. and S. V. won silver and bronze medals in the World Biathlon Championship, but in the general account of World Biathlon Cup competition they took only the $18^{\text {th }}$ and the $19^{\text {th }}$ places, and before that they had participated in competitions 19 and 14 times. World elite biathletes participated in E.ON and IBU category competitions $16.2 \pm 3.74$ times before the World Biathlon Championship. The number of starts correlates (Figures 1, 2 and 3) with the places taken by biathletes in the general standing of the World Biathlon Cup before the world championship $(r=-0.83)$, the places taken in the general standing of pursuit races $(r=-0.75)$, and sprint $(\mathrm{r}=-0.57)$. In the individual events in the World Biathlon Championship the medals were won by biathletes who had taken the $2^{\text {nd }}, 3^{\text {rd }}, 4^{\text {th }}$, $5^{\text {th }}, 6^{\text {th }}, 18^{\text {th }}$, and $19^{\text {th }}$ places in the general standing of World Biathlon Cup. Research results suggest that the number of starts in different distances in the World Cup competitions is related to the places taken by biathletes in the classification standing of those distances. Correlations between biathletes' taken places in different distances in World Cup competitions before the World Biathlon Championship and the places taken in the World Biathlon Championship are given in Figures 4 and 5 .The places taken by biathletes in the World Cup competitions (in all distances) correlate with the $1-10^{\text {th }}$ places taken in the World Biathlon Championship: with the places in pursuit competitions $r=0.70$, and with the places in sprint $\mathrm{r}=0.20$ (Figures 6 and 7). 


\begin{tabular}{|c|c|c|c|c|c|c|c|c|c|c|c|c|c|c|c|c|c|c|c|c|c|c|}
\hline \multirow{10}{*}{ 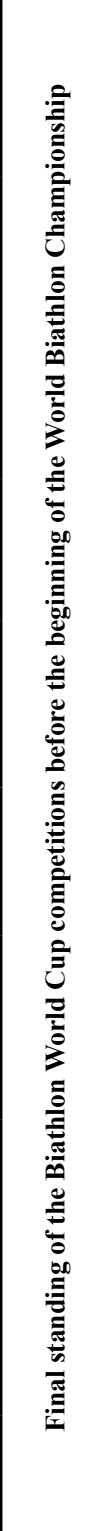 } & \multirow{2}{*}{ 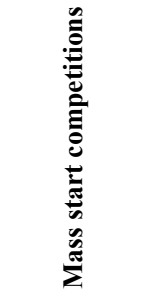 } & 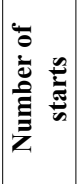 & $m$ & $m$ & $m$ & $N$ & $\mathrm{~m}$ & $N$ & $m$ & $m$ & $m$ & $m$ & $m$ & 1 & 10 & $n m$ & $\sim N$ & $m$ & $m$. & - & & 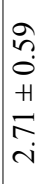 \\
\hline & & $\frac{\mathscr{E}}{\Theta}$ & $m$ & $\cong$ & $\simeq$ & $\stackrel{\circ}{\sim}$ & in & $\sim$ & $\ddot{\sim}$ & $=$ & $\triangleq$ & \pm & - & 1 & $1+$ & 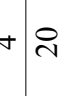 & 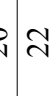 & $\infty$ & 0 & ले & 1 & \\
\hline & \multirow{2}{*}{ 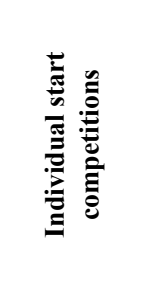 } & 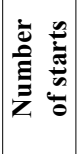 & $\sim$ & $m$ & $m$ & $m$ & $m$ & $m$ & $m$ & $m$ & $m$ & $m$ & $m$ & 1 & 10 & $n m$ & $n$ & $m$ & $m$ & $m$ & $v \mid$ & $\begin{array}{c}1 \\
\vdots \\
0 \\
+1 \\
2 \\
\infty \\
i \\
\text { in }\end{array}$ \\
\hline & & $\frac{\mathscr{E}}{\pi}$ & $\stackrel{0}{-}$ & $\nabla$ & 요 & - & 40 & $\stackrel{\Xi}{\sim}$ & $a$ & $\cong$ & 8 & $m$ & $n$ & 1 & 10 & $v \stackrel{\sim}{N}$ & 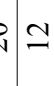 & 으 & సे & $\stackrel{\infty}{N}$ & ज़ & \\
\hline & \multirow{2}{*}{ 言 } & 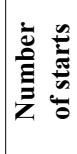 & $\nabla$ & $n$ & $m$ & $m$ & $n$ & $m$ & $\nabla$ & $n$ & $n$ & in & in & $m-$ & $-\nabla$ & $+n$ & $m$ & in & in & $n$ & +7 & $\begin{array}{c}\stackrel{\sim}{\exists} \\
= \\
+ \\
ت \\
\dot{+}\end{array} \mid$ \\
\hline & & $\frac{\mathscr{E}}{2}$ & $r$ & - & $\stackrel{\infty}{-}$ & 0 & $m$ & $\ddot{1}$ & $\nabla$ & $\infty$ & 으 & $a$ & 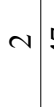 & 于 & 6 & $\therefore \equiv$ & $=\approx$ & $=$ & in & $\therefore=$ & $\vec{\nabla}$ & \\
\hline & \multirow[t]{2}{*}{ 泀 } & 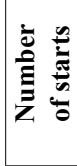 & 0 & $\infty$ & 0 & 0 & $\infty$ & 0 & $r$ & $\infty$ & $\infty$ & $\infty$ & $\infty$ & $0 /$ & $m \mid \infty$ & $\infty \quad \infty$ & 0 & $\infty$ & $\infty$ & $\infty$, & $-\sqrt{\vdots}$ & 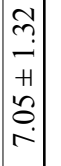 \\
\hline & & $\frac{\mathscr{E}}{\pi}$ & $m$ & - & $\infty$ & 0 & $\nabla$ & in & 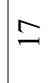 & \pm & a & $\cong$ & $N^{1}$ & F & $\overline{0} 0$ & $=\cong$ & $\infty \infty$ & $r$ & (0) & $\widehat{\sim}$ & ก & \\
\hline & \multirow{2}{*}{ 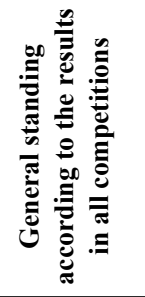 } & 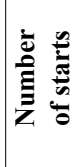 & $\because$ & 2 & \pm & \pm & 2 & \pm & $=$ & 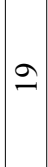 & $\cong$ & 2 & $\approx$ & $\cong$ & $\nabla \infty$ & $\infty$ & $\Delta$ & 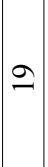 & 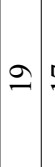 & $=8$ & 2 & 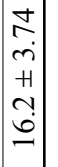 \\
\hline & & $\frac{\mathscr{E}}{2}$ & in & $N$ & \pm & $\cong$ & $\mathrm{m}$ & $\stackrel{2}{2}$ & $\nabla$ & $=$ & $\because$ & 이 & - & int & $\pm \infty$ & $\infty \stackrel{\infty}{=}$ & 02 & $a$ & 6 & خे & $\bar{n}$ & \\
\hline \multicolumn{3}{|c|}{ 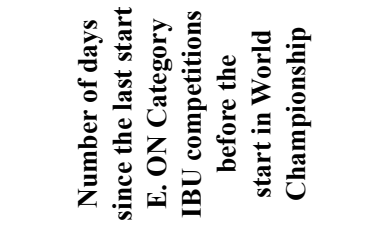 } & 9 & 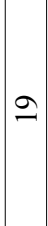 & $\stackrel{\sim}{\checkmark}$ & F & 9 & F & 9 & 9 & $\cong$ & 9 & 2 & $\underset{f}{ }$ & $\underset{+}{\infty}$ & $\partial \approx$ & S & 9 & 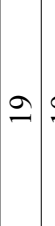 & 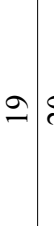 & 일 & 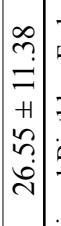 \\
\hline \multirow{4}{*}{ 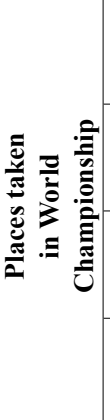 } & \multicolumn{2}{|c|}{$\begin{array}{l}\text { A.JPYS SSEW } \\
\text { WY S'ZI }\end{array}$} & - & $\nabla$ & $\stackrel{0}{\circ}$ & 0 & $r$ & $\cong$ & $m$ & $\infty$ & $\Xi$ & 0 & $\cong$ & $\stackrel{\infty}{\sim} \bar{\tau}$ & $\vec{\sim} \sigma$ & $\sim \simeq$ & 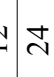 & in & $\sim:$ & I & 尺 & \\
\hline & \multicolumn{2}{|c|}{ 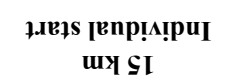 } & in & $\stackrel{\infty}{\sim}$ & $a$ & 1 & - & $r$ & 으 & 0 & 1 & $=$ & fo & 1 & 1 & 12 & $v e$ & 尺 & 2 & +0 & $\infty$ & \\
\hline & \multicolumn{2}{|c|}{$\begin{array}{l}\text { I!ns.Ind } \\
\text { UY 0I }\end{array}$} & $N$ & - & 6 & $\simeq$ & $m$ & 으 & in & $\because$ & $r$ & $\stackrel{\sim}{\sim}$ & $\nabla$ & $\infty \begin{array}{lll}\infty & 0\end{array}$ & a & I & $=$ & $\infty$ & $\tilde{m}$ & 0 & $\dot{m}$ & \\
\hline & \multicolumn{2}{|c|}{ 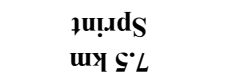 } & - & $\sim$ & $m$ & t & in & 0 & 1 & $\infty$ & $a$ & 으 & ¿ & $=\stackrel{2}{2}$ & $\underset{\sim}{\infty}$ & 寸 & $\stackrel{\infty}{-\infty}$ & $\Xi$ & is & 0 & $n$ & \\
\hline \multicolumn{3}{|c|}{ 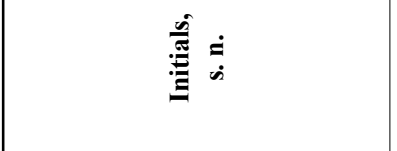 } & $\begin{array}{l}\dot{\Sigma} \\
\dot{z}\end{array}$ & $\begin{array}{l}\dot{v} \\
\dot{\Sigma}\end{array}$ & $\begin{array}{l}\dot{<} \\
\dot{1}\end{array}$ & $\stackrel{0}{0}$ & $\dot{j}$ & $\stackrel{4}{2}$ & $\ddot{\oplus}$ & $\begin{array}{l}\Sigma \\
\dot{a}\end{array}$ & $\begin{array}{l}\sum \\
\dot{0}\end{array}$ & $\dot{\vec{s}} \overrightarrow{\dot{s}}$ & $\mid \begin{array}{l}\dot{\Sigma} \\
\dot{1} \\
\end{array}$ & : & \begin{tabular}{l|l}
$\theta$ & $\sum$ \\
$\dot{z}$ & $\infty$
\end{tabular} & $\begin{array}{l}\sum \\
\dot{\varphi} \\
\dot{\varphi}\end{array}$ & $\dot{\dot{a}} \overrightarrow{\dot{\nu}}$ & $\begin{array}{l}\dot{H} \\
\dot{v}\end{array}$ & $\dot{\dot{\theta}} \dot{\dot{\theta}}$ & $\begin{array}{l}\dot{z} \\
\dot{s} \\
\dot{s}\end{array}$ & & $\begin{array}{l}a \\
\tilde{\infty} \\
+1 \\
x\end{array}$ \\
\hline
\end{tabular}


Figure 1. Relationship between biathletes' places in the general standing in the Biathlon World Cup competitions before the World Biathlon Championship and the number of their starts in World Cup competitions

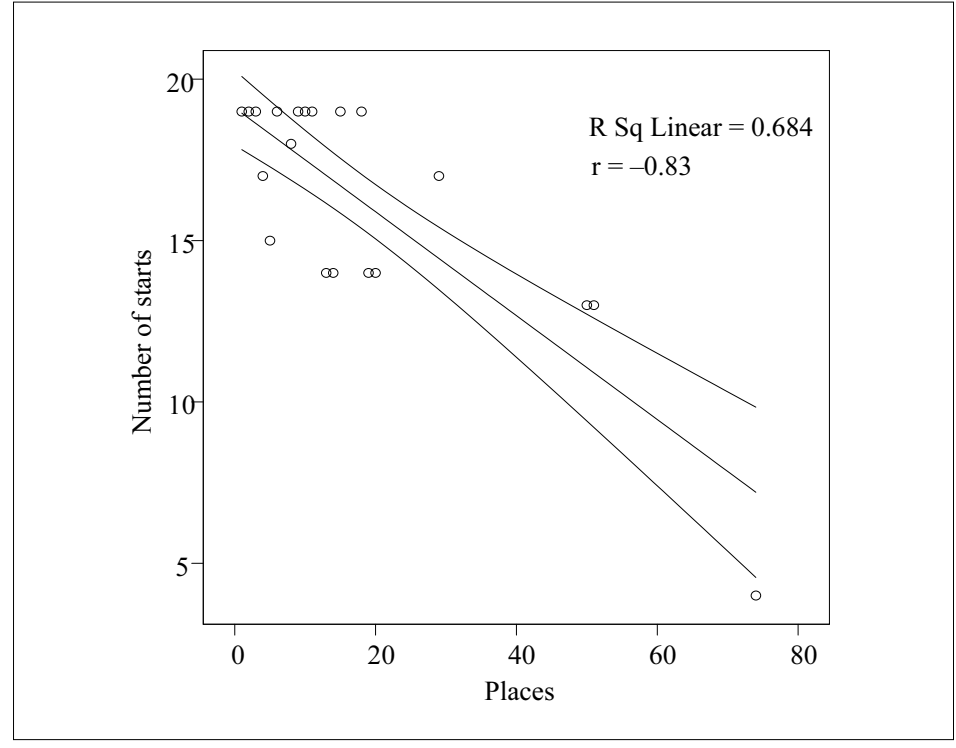

Figure 2. Relationship between biathletes' places in the general standing in the Biathlon World Cup pursuit races before the World Biathlon Championship and the number of their pursuit starts in World Cup competitions
Figure 3. Relationship between biathletes' places in the general standing in the Biathlon World Cup sprint competitions before the World Biathlon Championship and the number of their sprint starts in World Cup competitions
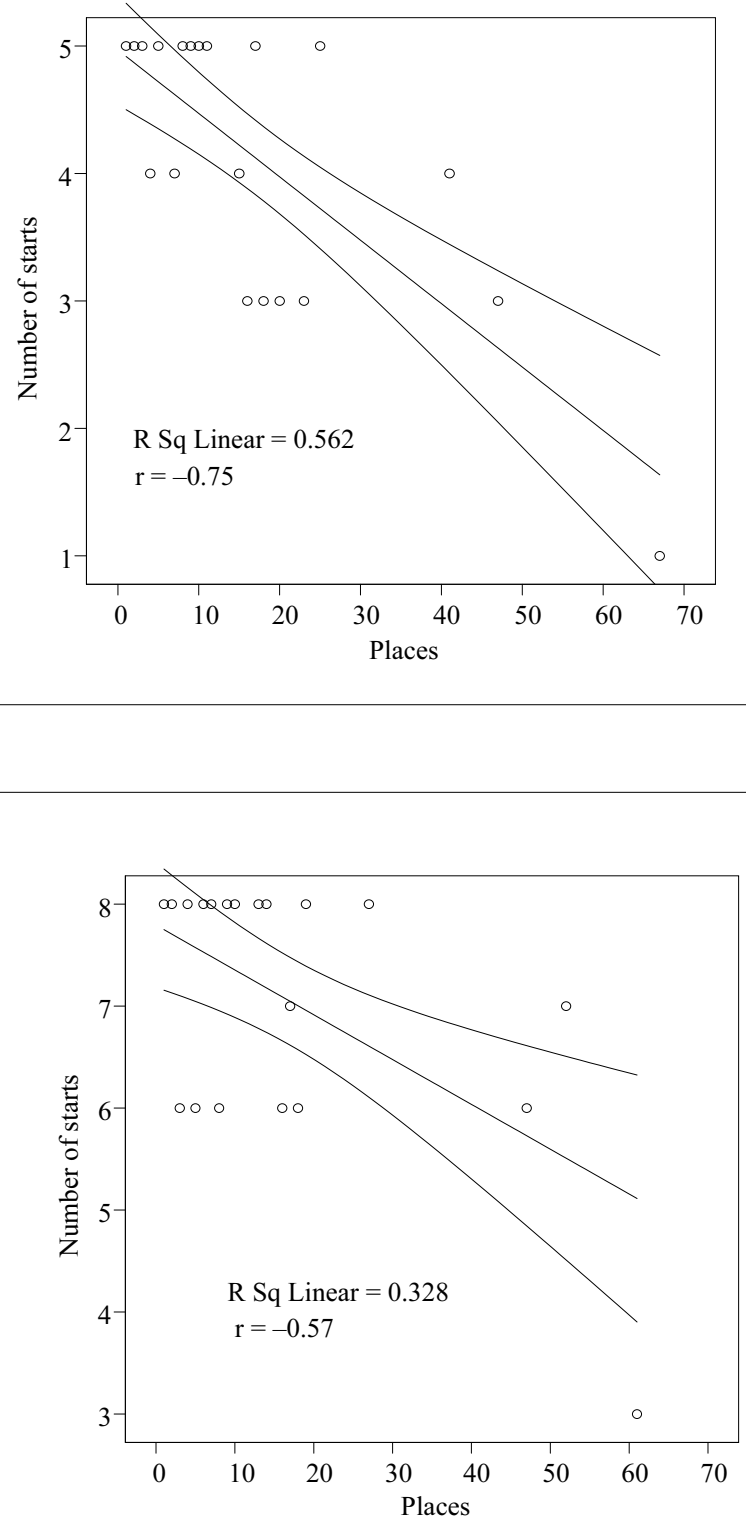

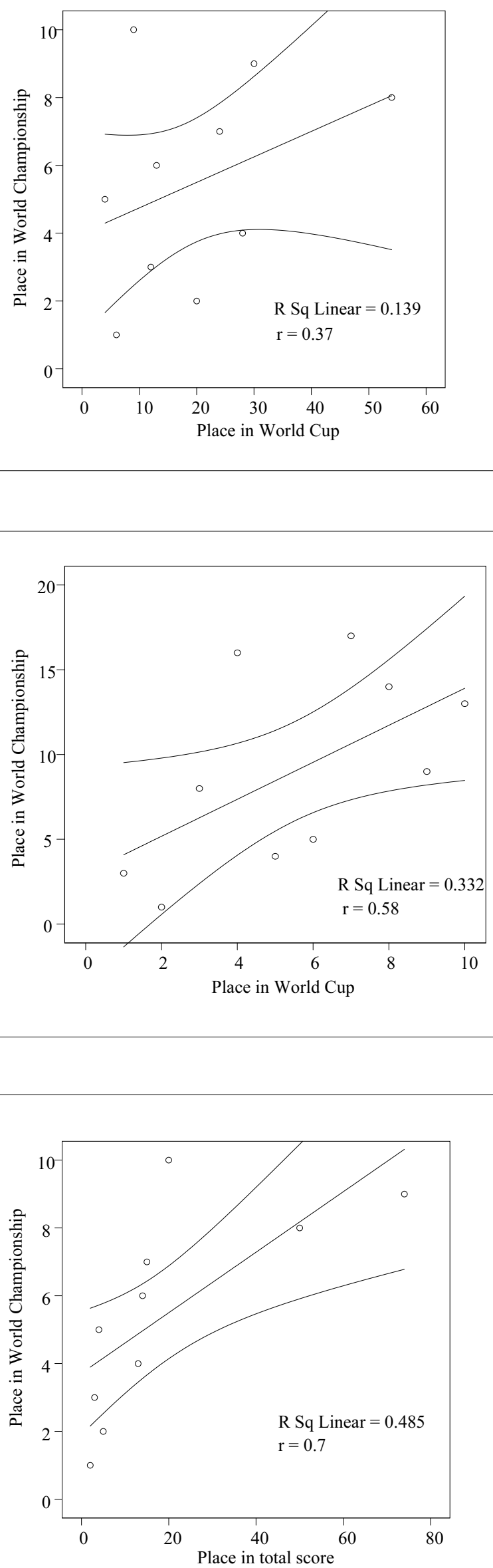

Figure 4. Relationship between biathletes' $1^{\text {st }-10^{\text {th }}}$ places in the individual start competitions in World Biathlon Championship and the places taken in the general standing in the Biathlon World Cup individual competitions before the World Biathlon Championship

Figure 5. Relationship between biathletes' $1^{\text {st }}-10^{\text {th }}$ places in the general standing in the Biathlon World Cup sprint competitions before the World Biathlon Championship and the places taken in sprint in the World Biathlon Championship
Figure 6. Relationship between biathletes' $\mathbf{1}^{\text {st }}-10^{\text {th }}$ places in the pursuit competitions in the World Biathlon Championship and the places in the general standing in the Biathlon World Cup competitions in all distances before the World Biathlon Championship and the places taken in pursuit 
Figure 7. Relationship between biathletes' places in the general standing in the Biathlon World Cup competitions in all distances before the World Biathlon Championship and places taken in sprint in the World Biathlon Championship

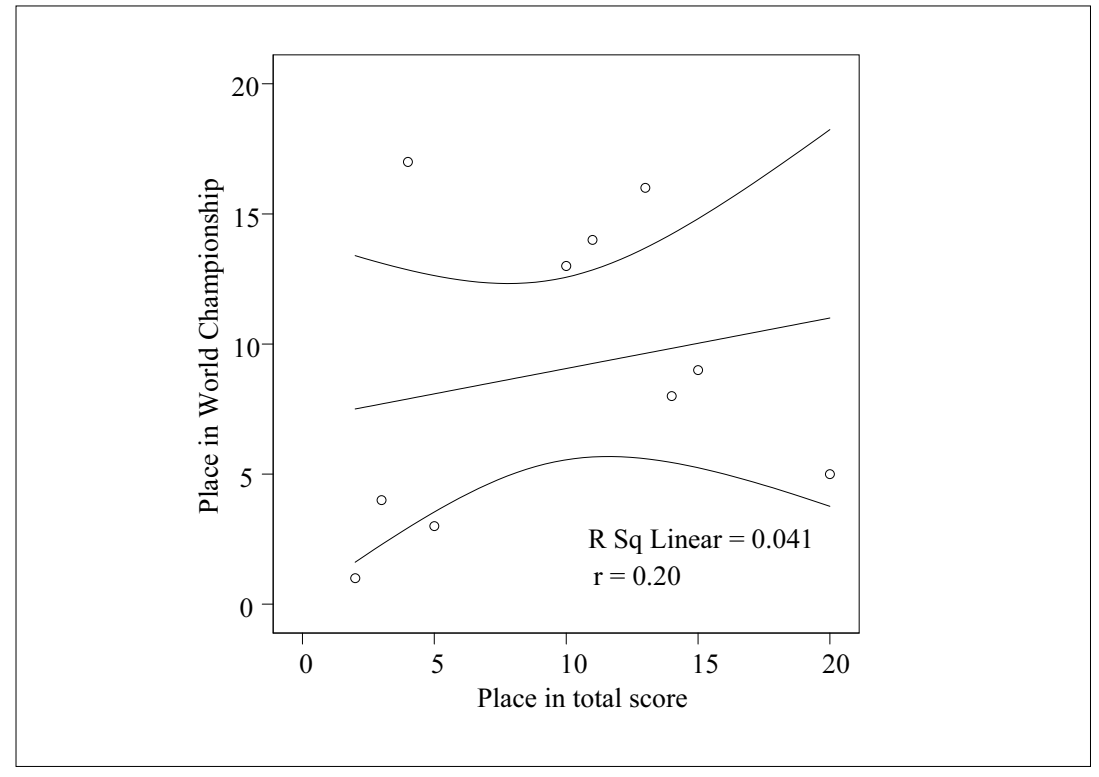

\section{DISCUSSION}

In biathlon the time of the run includes the time the biathlete spends on the course without the time spent for shooting. The most important factor influencing running time includes the level of physical fitness as well as technical and tactical preparation (Cholewa et al., 2005).

Because of the complexity of tasks in the biathlon, achieving a world class level by a talented athlete requires 8-12 years of systematic training aimed at developing a high level of physical and psychomotor fitness as well as great skiing and shooting skills (Rundel, Szmedre, 1998; Ryguła, 2002). It is evident that creating proper external conditions allows for the development of the internal potential of a particular athlete, which guarantees the achievement of world class results (Rundell, Bacharach, 1995).

Good sports shape of an athlete is related to the appropriately chosen number of starts and their distribution in the mesocycles of the competition period (Bompa, 1999; Suslovas, 1999; Платонов, 2009). Appropriately planned competitions considering the terms of relevant competitions help acquire the sports shape (Платонов, 2009).

Research results (Table) show that female biathletes who won medals in the World Biathlon Championship had participated 14-19 times in biathlon competitions before the championship. Biathlete N. M. having won two gold and one silver medals had 15 starts before the beginning of the championship. Elite biathletes are universal, and they participate in sprint, individual start, mass start and pursuit races. The majority of elite biathletes did not participate in any competition 19 days before the beginning of the World Championship E.ON IBU category competitions (Table).

The strategy of biathletes' preparation for the world championship corresponds to the approach of sports training periodization (Платонов, 2009) stating that frequent participation in competitions before the main competition of the season requires a special preparation phase for the main starts. Before the beginning of the world championship, elite biathletes participated in the competitions of different distances: sprint $-7.05 \pm 1.32$ times, pursuit $-4.10 \pm 1.12$ times, individual start races $2.89 \pm 0.32$ times, mass start races $-2.71 \pm 0.59$ times (Table).

The correlations between biathletes' places in the general standing in the Biathlon World Cup competitions in different distances before the World Biathlon Championship and the places taken in the same distances in the World Biathlon Championship are weak - in individual start competitions 0.37 , in sprint they are higher 0.58 . We established that the $1^{\text {st }}-10^{\text {th }}$ places taken by biathletes in the general classification (in all distances) during the World Cup competitions before the championship strongly correlated 
$(\mathrm{r}=0.70)$ with their places in pursuit competitions in the World Championship.

In the individual races in the World Championship, all medals were won by eight skiers, and five of them were among the first ten skiers in the general standing of World Cup competitions before the world championship. It is worth noting that in the $15 \mathrm{~km}$ individual start competition, the fourth pace was taken by S. N. who was only $29^{\text {th }}$ in the general classification before the World Championship. We suggest that biathletes who have taken the $1-10^{\text {th }}$ places in the general standing in the Biathlon World Cup competitions are real applicants to win medals in the World Biathlon Championship.

\section{CONCLUSION AND PERSPECTIVES}

The preparation of elite biathletes for the most important competition of the season World Biathlon Championship is grounded on the repeated participation in the World Biathlon Cup competitions. The places taken in the general standing of the World Biathlon Cup are the indices of biathletes' mastery and stability. Biathletes, taking the $1^{\text {st }}-10^{\text {th }}$ places in the general standing of the World Biathlon Cup, are real applicants for medals in the World Biathlon Championship.

Modern training trend of elite biathletes is the individual optimization of competition activities according to individual training plan for the most important competition of the season.

\section{REFERENCES}

Biathlon $^{1}$. Biography. Athlete information. Internet link: http://www.biathlonworld3.de.html

Biathlon $^{2}$. Datancenter. Internet link: http://www. biathlonworld3.de/en/home.html

Biathlon $^{3}$. E. ON IBY World Cup 2010-2011. Internet link: http://www. biathlonworld3.de.html

Biathlon $^{4}$. World Championship 2011. Internet link: http://www.biathlonworld3.de.html

Bompa, T. O. (1999). Periodization: Theory and Methodology of Training. $4^{\text {th }}$ ed. United States: Human Kinetics.

Cholewa, J., Gerasimuk, D., Szepelawy, M., Zajac, A. (2005). Analysis of structure of the biathlon runs. Acta Universitatus Palackianae Olomucensis, Gymnica, 35 (1), 35-42.

Pustovrh, J., José, B., Vodicar, J. (1995). Analysis of the structure of competitive successfulness in the biathlon. In Acta Kinesiologiae Universitatis Tartuenssi (pp. 171185). Tartu.

Rundell, K., W., Bacharach, D. W. (1995). Physiological characteristics and performance of top U. S. biathletes. Medicine and Science in Sports and Exercise, 9, 13021310.

Rundell, K. W., Szmedre, L. (1998). Energy cost of rifle carriage in biathlon skiing. Medicine and Science in Sports and Exercise, 30, 570-576.
Ryguła, I. (Ed.). (2002). Elementy teorii, metodyki, diagnostyki I optymalizacji treningu sportowego. Katowice: Akademia Wychowania Fizyczniego.

Schmolinsky, G. (2000). Track and Field: The East German Textbook of Athletes. Toronto: Sport Books Publisher.

Suslovas, F. (1999). Individualių sporto šakų varžybų sistema šiuolaikiniame sporto raidos etape. Treneris, 2, 22-31.

Платонов, В. Н. (2004). Система подготовки спортсменов в олимпийском спорте. Общая теория и её практические приложения. Киев: Олимпийская литература.

Платонов, В., Н. (2009). Теория периодизации спортивной тренировки в течении года: история вопроса, состояние, дискуссии, пути модернизации. Теория и практика физической культуры, 9, 18-34.

Преображенцев, Ю. Ф. (2007). Сравнительный анализ соревновательной деятельности сильнейших биатлонистов в сезоне 2006-2007 г. г. Сборник научных трудов, посвящённый 70-летию образования кафедры теории и методики лыжного спорта РГУФК (сс. 32-38). Москва: РГУФК.

Суслов, Ф. П. (2002). О стратегии соревновательной практики в идивидуальных видах спорта в олимпийские годы. Теория и практика физической культуры, 11, 30-33. 


\title{
ELITO BIATLONININKIŲ SPORTINIŲ REZULTATU PASAULIO TAURĖS VARŽYBOSE IKI PASAULIO ČEMPIONATO IR REZULTATŲ ČEMPIONATE LYGINAMOJI ANALIZE PER 2010-2011 M. SEZONĄ
}

\author{
Natalja Kočergina, Algirdas Čepulènas, Aurelijus Zuoza \\ Lietuvos kūno kultūros akademija, Kaunas, Lietuva
}

\begin{abstract}
SANTRAUKA
Tyrimo pagrindimas ir hipotezé. Elito biatlonininku šiuolaikinè treniravimo kryptis - treniravimo vyksmo intensyvinimas per varžybinę veiklą. Elito biatlonininkių varžybinè veikla rengiantis pagrindinèms sezono varžyboms dar mažai tirta. Tyrimu tikrinama hipotezè, kad elito biatlonininkių startų skaičius ir sportiniai rezultatai iki pagrindinių sezono varžybų turi sąveikos ryšiu su sportiniais rezultatais pagrindinèse sezono varžybose.

Tikslas - išnagrinèti elito biatlonininkių sportinių rezultatų sąveiką su startų skaičiumi ir nustatyti sąveikos ryši tarp rezultatu, pasiektų Pasaulio taurès varžybose iki pasaulio čempionato ir rezultatų pasaulio biatlono čempionate.

Metodai. Duomenys paimti iš Tarptautinès biatlono federacijos (IBU) dokumentų: $2011 \mathrm{~m}$. pasaulio biatlono čempionato varžybų protokolų, Pasaulio biatlono taurès varžybų dokumentų. Analizavome sportinius rezultatus biatlonininkių, kurios pasaulio biatlono čempionate individualiose rungtyse užèmè $1-10$ vietas.

Rezultatai. Pasaulio elito biatlonininkès iki pasaulio čempionato dalyvavo 16,2 $\pm 3,74$ kartų E.ON bei IBU kategorijos varžybose.

Startų skaičius turi koreliacijos ryšių su biatlonininkių užimtomis vietomis Pasaulio taurès varžybų bendrojoje iskaitoje iki pasaulio čempionato pradžios $(\mathrm{r}=-0,83)$. Per pasaulio čempionatą individualios programos lenktynejse visus medalius laimėjo aštuonios biatlonininkès ir iš jų penkios Pasaulio taurės varžybų bendrojoje įskaitoje iki pasaulio čempionato pradžios buvo pirmajame dešimtuke.

Aptarimas ir išvados. Pasaulio elito biatlonininkių pasirengimas svarbiausiam sezono startui - pasaulio čempionatui pagristas dažnu dalyvavimu Pasaulio biatlono taurès varžybose. Biatlonininkès, Pasaulio biatlono taurès varžybų bendrojoje ịskaitoje užimančios vietas pirmame dešimtuke, yra realios pretendentès laimèti medalius pasaulio čempionate.
\end{abstract}

Raktažodžiai: startu skaičius, užimtos vietos, koreliacija, sprintas, persekiojimo lenktynès, masinis startas, individualus startas. 